\title{
The Biology, Epidemiology, and Management of Rice Tungro Disease in Asia
}

Many farmers in South and Southeast Asia describe rice tungro disease as a cancer disease because of the severe damage it causes and the difficulty of controlling it (121). As the most important of the 14 rice viral diseases, tungro was first recognized as a leafhopper-transmitted virus disease in 1963 (88). However, tungro, which means "degenerated growth" in a Filipino dialect, has a much longer history. It is almost certain that tungro was responsible for a disease outbreak that occurred in 1859 in Indonesia, which was referred to at the time as mentek (83). In the past, a variety of names has been given to tungro, including accep na pula in the Philippines, penyakit merah in Malaysia, and yelloworange leaf in Thailand (83).

From the 1960 s to the mid-1970s, there was a huge increase in the area planted with modern high-yielding and early-maturing rice varieties that required reliable irrigation and high inputs of fertilizer. Such intensive cropping systems, which were characterized by a short canopy crop with a continuous rice planting, delivered impressive increases in rice grain yield (111), but also were conducive to the development of rice plant- and leafhoppers populations and to the spread of viruses that they vectored. Therefore, during this period, a series of large-scale outbreaks of tungro was recorded in India, Thailand, Indonesia, Malaysia, and Philippines. Rice farmers and poor consumers suffered severe hardship during these outbreaks, and the threat to food security in the regions affected gave the disease a high political profile (114). The difficulty in forecasting outbreaks and the rapidity of disease spread as epidemics developed created a problem of alarming dimensions. With severe infections, total loss of grain yield occurred and many farmers dependent on credit to purchase inputs were not in a position to repay their loans. The frequency and intensity of

Corresponding author: Osmat Azzam, Monticello Research Australia, 135 Wickerslack Lane, Googong, NSW 2620, Australia;

E-mail: osmat@cambia.org

Publication no. D-2001-1207-01F

(C) 2002 The American Phytopathological Society major tungro epidemics have declined since the peak that was reached in the late 1960 s to the mid-1970s. However, the disease remains a serious threat in endemic areas in Philippines and Indonesia (Table 1) and periodically emerges as a significant problem in eastern India and parts of Bangladesh $(2,35)$. The areas where tungro is endemic are small in relation to the total rice production of the region. However, these endemic areas constitute sources from which the disease can potentially spread to other localities and develop into large-scale outbreaks (109). Many farmers in areas where tungro occurs infrequently still view the disease as an important constraint to rice production (121). This is especially true where rice production is the main source of a farmer's livelihood and where the farm household has limited ability to absorb the shock of one total crop failure. Lenné (67) has drawn attention to the fact that pest problems tend to affect poor households disproportionately, and this is a characteristic feature of subsistence rice farming in Asia.

The development of appropriate methods to manage tungro was constrained for a long time by a limited knowledge of the epidemiology of the disease and the ecology of its leafhopper vectors. The need to produce rice varieties with resistance to tungro and to its main vector, Nephotettix virescens (Distant), was recognized in the mid-1960s as the scale of the disease problem became apparent. Early breeding programs were hampered by the absence of a suitable technique for discriminating be- tween vector and virus resistance. Added to this, it was not until the late 1970s that it was confirmed that two viruses were associated with the disease (54). A serological assay was then developed for each of the viruses, and serology remains the most widely used diagnostic method for breeding work and epidemiological studies (13). Most of the resistant varieties released by the International Rice Research Institute (IRRI) and by national breeding programs had resistance to the vector and not to the viruses. These varieties made a major contribution to reducing the incidence of tungro, but in many cases the resistance was not durable and new varieties had to be introduced as the old ones became ineffective (33).

Recent developments in tungro research have focused on two main areas: firstly, on the conduct of epidemiological studies to form the basis for the development of improved tungro management strategies; secondly, on the breeding of virus-resistant varieties, using both conventional and transgenic approaches, to provide options for tungro management programs. In parallel with the breeding of these virus-resistant varieties, research has been carried out on virus variation and genetic structure of tungro virus populations in different geographical areas. This article is intended to present an overview of these research findings and to show how they are being used to help farmers manage a complex disease that has been such an intractable problem over a long period of time. The continuing intensification of rice production systems

Table 1. Major recorded outbreaks ( $\geq 4,000$ ha) of tungro disease in Asia during the past 20 years

\begin{tabular}{llcc}
\hline Year & Location & Affected area (ha) & Reference \\
\hline 1980 & Indonesia (Bali) & 16,000 & 73 \\
$1982-83$ & Malaysia (MADA) & 20,365 & 28 \\
$1983-84$ & Indonesia (Bali, Java, Sumatra) & 25,000 & 74 \\
$1983-84$ & Philippines & $\geq 4,000$ & 14 \\
$1984-85$ & India (Tamil Nadu, Andhra Pradesh) & 80,000 & 47 \\
$1985-86$ & Indonesia (Bali, Java, Sumatra, & 18,000 & 74 \\
& Kalimantan, Irian Jaya) & 183,000 & 85 \\
$1990-91$ & India (Andhra Pradesh, Orissa) & 12,340 & 34 \\
1995 & Indonesia (Central Java) & 4,000 & Govt. records \\
$1997-98$ & Philippines (Mindanao) & &
\end{tabular}


in Asia and the requirement to produce more grain from a declining agricultural land area using less water and less labor make this an important challenge.

\section{Biological Determinants of Rice Tungro Disease}

Causal agents. In 1979, tungro was found to be associated with two viruses (Fig. 1): an RNA virus, Rice tungro spherical virus (RTSV), and a DNA/RNA virus, Rice tungro bacilliform virus (RTBV) (54). Based on the availability of many sources of resistance against RTSV in the endemic countries, it is believed that the virus has coevolved with rice in that part of the world; whereas the lack of resistance against RTBV suggests a more recent introduction of this virus in South and Southeast Asia. The two viruses interact to allow disease development and to enable full symptom expression to occur (46). RTBV is a pararetrovirus and is a member in the family Caulimoviridae (Fig. 1A). RTBV depends on the helper produced by RTSV for its own transmission and is mainly responsible for the severe tungro symptoms. RTBV packages its $8-\mathrm{kb}$ genome as double-stranded DNA that has two discontinuities, one in each strand (59). In common with other plant pararetroviruses, RTBV is transcribed asymmetrically with all the coding capacity on the negative strand. The virus has four open reading frames (ORFs), capable of encoding proteins of 24, 12, 194, and 46 $\mathrm{kDa}$, respectively $(41,84)$. ORF3 encodes a P194 polyprotein that contains four functional domains: the viral coat protein (37 $\mathrm{kDa}$ ), aspartate protease, reverse transcrip- tase, and ribonuclease $\mathrm{H}$ (59). Alignment of several sequences of RTBV variants revealed highly conserved regions in the functional domains of ORF3 and showed some variation in the cysteine-rich region, suggesting that this domain carries adaptive changes (21).

RTSV, a member of the family Sequiviridae, acts as a helper virus for the transmission of RTBV (Fig. 1B). RTSV has a polyadenylated single-stranded RNA genome of about $12 \mathrm{~kb}$ that is encapsidated within isometric particles (99). The genome encodes a single large ORF of 3,473 amino acids (99). RTSV strains cannot be distinguished serologically but do differ significantly at the molecular level. Recently, it was shown that a virus strain (RTSV-Vt6), which has higher virulence to RTSV-resistant rice variety TKM6 than the

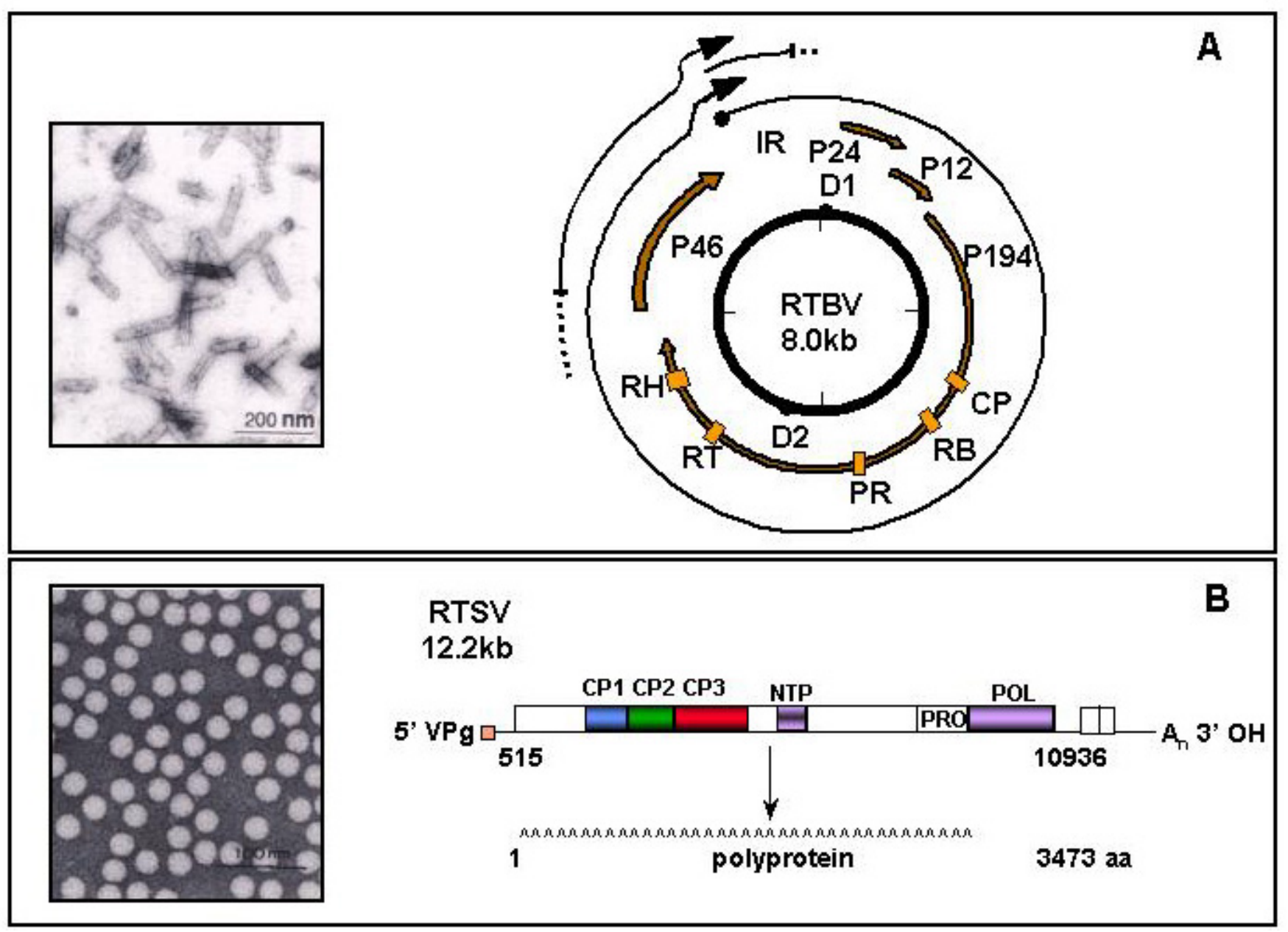

Fig. 1. The two causal agents of tungro disease. A, Electron micrograph of rice tungro bacilliform virions and the viral genome organization. Inner circle represents double-stranded DNA genome of Rice tungro bacilliform virus (RTBV) (8.0 kb) with sites of two discontinuities, D1 and D2. Arcs show the positions of open reading frames (ORFs) with sizes of the proteins they encode in kDa. On the polyprotein ORF, P194, the position of the N-terminus of 37-kDa coat protein (CP) is shown and suggested motifs of RNA binding site (RB), aspartate protease (PR), reverse transcriptase (RT), and RNase $H(R H)$ are also represented. The intergenic region (IR) is shown between P46 and P24 ORFs. Outer circle and arc show the more than full-length and spliced transcripts, respectively. $B$, Electron micrograph of rice tungro spherical virions and the viral genome organization. The single-stranded RNA genome of Rice tungro spherical virus (RTSV) $(12.2 \mathrm{~kb})$ is shown as a single line and coding regions as colored boxes. The genome has a suggested covalently linked protein $(\mathrm{Vpg})$ at its $5^{\prime}$ end and a poly(A) sequence at its $3^{\prime}$ end. It encodes a large polyprotein $(3,473$ amino acids) that starts after the $\mathbf{5 1 5}$ nucleotides leader sequence. The genome also has two short unidentified ORFs at the $\mathbf{3}^{\prime}$ end. Positions of the three coat proteins (CP1, CP2, and CP3), and of motifs for nucleotide triphosphate binding domain (NTP), protease (PRO), and polymerase (POL) are represented. 
type strain from the Philippines (RTSV-AShen), differed markedly in a 39-amino acid region in the $\mathrm{N}$-terminal leader sequence (63).

Because rice varieties react differentially to single or dual infections with RTBV and/or RTSV and express variable symptoms $(32,52)$, separating the two viruses and comparing their symptoms on and infectivity to differential varieties was an essential step to identifying tungro variants. Using this approach, two variants of RTSV were recognized based on their reaction in rice variety TKM6, and four variants of RTBV were recognized based on their reaction in rice variety $\mathrm{FK} 135$ in the Philippines (17). With the availability of molecular tools to study tungro viruses, genetic variability of both viruses was further analyzed and confirmed in cloned and natural virus populations. When cloned RTBV genomes from Bangladesh, India, Malaysia, Indonesia, and Thailand were compared with the fully characterized genome of the Philippine isolate, two groups of RTBV isolates were identified, those from the Indian subcontinent and those from Southeast Asian countries, using restriction endonuclease maps, partial sequence analysis, and cross hybridization
(37). Microvariation within the RTBV Southeast Asian group was also confirmed (120). Similar grouping was reported for RTSV isolates from Bangladesh, India, Malaysia, Thailand, and the Philippines based on the analysis of their coat protein gene (125).

Disease symptoms and effects on yield. Symptoms of tungro disease in rice plants vary according to the age of the plant, rice variety, and virus strains. The most conspicuous symptoms of rice plants infected with both RTSV and RTBV are stunting and yellow to orange discoloration of the leaves (89). Yellowing of the tips of young leaves is the first symptom to appear, and this may include interveinal chlorosis or chlorotic mottling (Fig. 2A). When plants are infected at an early stage of growth, few tillers are produced, root development is poor, and stunting is very severe. Panicles that develop on severely infected rice plants are small, and any seeds set are often deformed and not viable $(69,89)$. In infected plants, RTBV is localized in the vascular bundles, and RTSV is restricted to the phloem tissues (107). Virus infection results in a decreased level of soluble sugars and an increased level of starch and total amino acids (105). Rice and other host plants infected only with RTSV generally show mild stunting, which is difficult to detect (48). An exception to this is an accession of Oryza glaberrima (IRGC 100139) which displays marked stunting and pale green, narrow and erect leaves (19). A virulent form of RTSV appeared in Japan in the 1970s and caused a condition that was termed rice waika disease. Plant height was reduced by about $20 \%$, and grain quality was much reduced (83). Rice plants infected with RTBV generally show mild yellowing and stunting (53). In glasshouse trials, yield losses reached $70 \%$ when plants were infected 10 days after sowing, and losses were reduced to $5 \%$ when infection was delayed to 75 days after sowing (71).

Tungro diagnosis. Tungro disease is not always easy to identify in the field, as characteristic symptoms are not expressed in all varieties (40). Tungro may be detected by the iodine/starch test or through the use of insect transmission tests to assay plants. However, the iodine/starch test, which shows simply an increased accumulation of starch in infected plants, is not always reliable or specific, and insect transmission tests are laborious. Where suitable laboratory facilities are available,
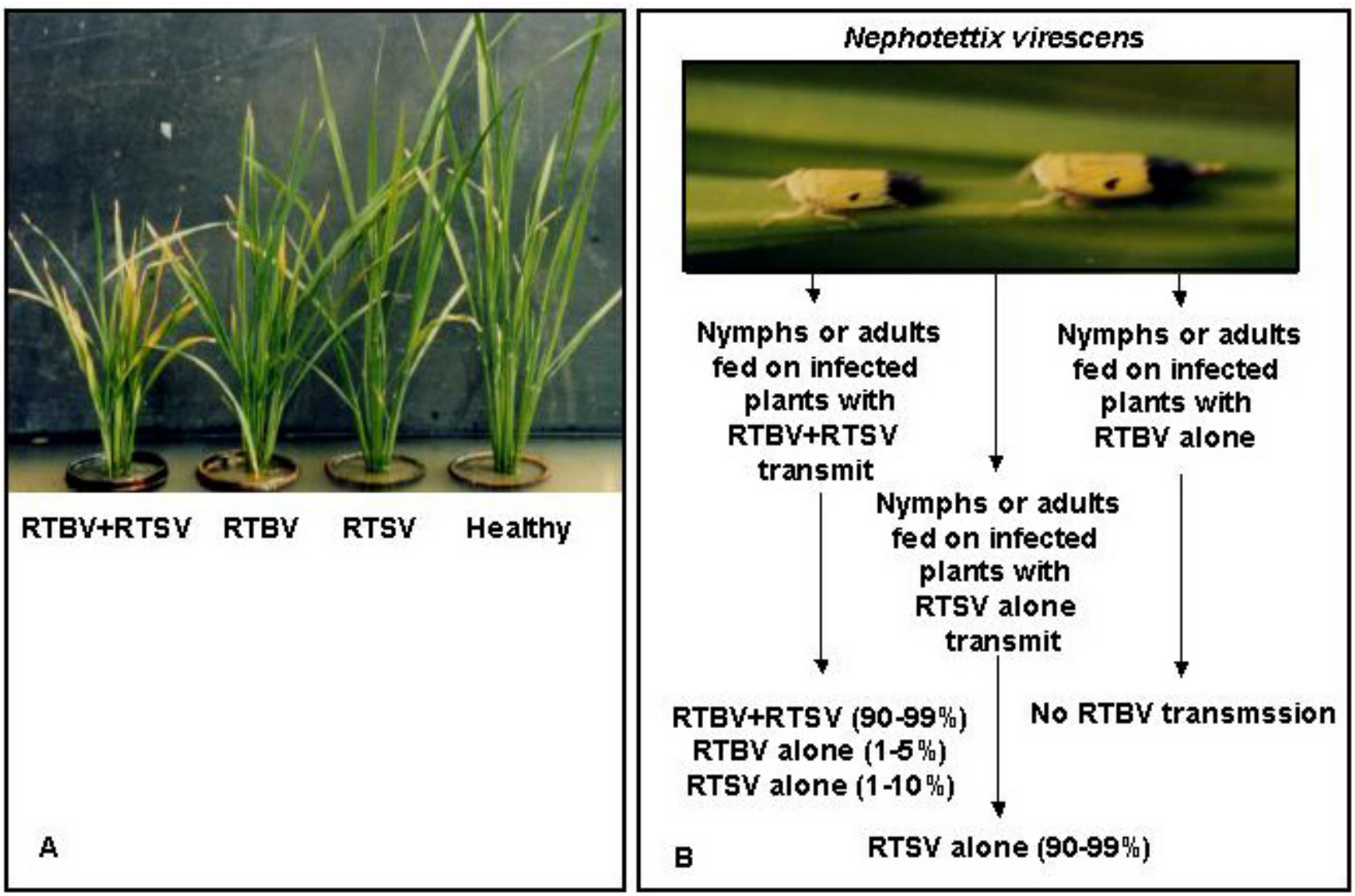

Fig. 2. Symptoms of rice tungro viruses on a susceptible rice variety and tungro transmission process by the leafhopper vector, Nephotettix virescens. A, Infection with both Rice tungro bacilliform virus (RTBV) and Rice tungro spherical virus (RTSV) induces severe stunting and distinct orange-yellow leaf discoloration. Infection with RTBV alone induces mild stunting with some yellowing of rice leaves, whereas infection with RTSV alone induces no apparent symptoms and the rice plant looks similar to a healthy plant. $B$, Transmission of both viruses by $N$. virescens requires that the insects feed on plants infected by both viruses. Insects can transmit RTSV alone, but they cannot transmit RTBV unless RTSV is present. 
serological techniques are used to detect tungro viruses, as these techniques are relatively specific, sensitive, and reliable (81). A double-antibody sandwich enzymelinked immunosorbent assay (DASELISA) is used to screen breeding lines for tungro virus resistance or tolerance (52). DAS-ELISA is also used for disease surveys and epidemiological studies $(12,115)$. Nevertheless, DAS-ELISA is not widely used in rice-growing countries where tungro is prevalent because resources are rarely sufficient to produce antisera and to purchase the necessary equipment and reagents. Similar considerations apply to the use of a polymerase chain reaction technique that has been developed as a sensitive test for RTBV in tolerant cultivars (112). In view of these constraints, attempts have been made to develop alternative serological methods such as Parafilm mini-ELISA and rapid immunofilter paper assay (20). More recently, a relatively simple and inexpensive diagnostic kit has been developed for RTBV detection based on a tissue-print assay (78). The kit should prove to be useful to rice breeders and agricultural extensionists in tungroendemic countries, but it needs further development before it is made more widely available.

Leafhopper vectors. Tungro viruses are transmitted by six leafhopper species, five of which are in the genus Nephotettix. Due to its close biological relationship with rice, the rice green leafhopper $N$. virescens (Distant) (Fig. 2) is by far the most important vector species (50). N. virescens has a higher transmission efficiency than other vector species and is usually more abundant in irrigated rice fields. Recilia dorsalis (Motschulsky) is an inefficient vector of tungro viruses, but it may be important in some locations, as large numbers have been recorded on rice seed beds and levees (30). N. virescens lays its eggs in batches of up to 44 in the tissues of the leaf sheath of rice tillers (29). After hatching, there are five nymphal stages before adult emergence. At the optimum temperature for development $\left(30\right.$ to $35^{\circ} \mathrm{C}$ ), a generation can be completed in ca. 25 days so that up to 11 generations a year are possible in tropical areas where there is continuous rice cultivation $(118,119)$.

Virus-vector interactions. RTSV and RTBV are transmitted in a semipersistent manner by the leafhopper vectors so that they are retained by the insects for periods up to 1 week. RTSV can be spread independently of RTBV (Fig. 2B), and the virus has been found to be widely distributed in irrigated rice areas in the Philippines (12). By contrast, RTBV may be transmitted only after leafhoppers feed on source plants infected with both RTSV and RTBV, or when they acquire RTSV first and then RTBV (18). It has been suggested that a virus-encoded noncapsid helper component is involved, but no detailed research has been conducted to confirm this (49). On susceptible rice varieties, leafhoppers feed predominantly in the phloem (104). However, on resistant varieties, feeding is mainly in the xylem, phloem ingestion being inhibited by antibiosis (6). $N$. virescens can acquire virus from a susceptible rice variety after a feeding period of $30 \mathrm{~min}$ (88). There is no latent period in the insect, and the viruses can be transmitted immediately after acquisition during feeding periods of only a few minutes (70). Leafhoppers retain the ability to transmit RTSV and RTBV for approximately 4 and 7 days, respectively (50). Nymphal stages can also transmit RTSV and RTBV, but lose infectivity after molting (68). Rice plants can become effective sources of inoculum within 1 week of infection (77). This short latent period, combined with the short feeding periods needed for acquisition and transmission of the viruses, creates the potential for very rapid spread of tungro disease.

\section{Dynamics of Rice Tungro Disease}

Ecology of the leafhopper vectors. Nephotettix spp. differ widely in their range of preferred hosts. The main tungro vector, $N$. virescens, is monophagous and is restricted to $O$. sativa and some closely related wild rices. In the break between rice crops, $N$. virescens survives on regenerated growth from rice stubble and on volunteer plants. In areas where rice plants are established by transplanting seedlings, rice seedbeds can be colonized by leafhoppers (30). Immigrants may lay eggs in seedbeds, but young seedlings are not suitable for oviposition. As early nymphal stages are rarely seen during population sampling in the first 2 weeks after transplanting, egg laying in seedbeds does not appear to be important for leafhopper colonization in the main crop $(24,30)$. The situation may be different where older seedlings are transplanted, as in the Krian irrigation scheme in Malaysia where large numbers of $N$. virescens were recorded in nurseries on seedlings up to 45 days of age (15).

Immigration of leafhopper adults into rice crops occurs from other rice crops, regenerated rice plants, volunteers, or in the case of some species, weeds. Earlyseason immigration rates are greatest in areas where planting dates are highly variable and where overlapping crops are found (123). In a study conducted in the Philippines, numbers of immigrants were greater in rainy seasons that extend from May to November than in dry seasons but were also high in a dry season crop that was planted much later than the neighboring fields (24). In irrigated rice areas where tungro is a problem, immigrant populations of $N$. virescens are much larger than those of other vector species. $N$. virescens is not a strong flier and usually disperses over relatively short distances, although trapping studies suggest that movement over distances up to at least $30 \mathrm{~km}$ can take place (87). In intensively cultivated rice areas where fallow periods are short, there is no selective advantage in adaptations for long-distance flight, and unlike some of the rice planthoppers, there are no specialized flight morphs (31).

In rainy seasons, there is a rapid buildup in numbers of $N$. virescens, and peak population densities are reached by midseason $(24,30)$. Further development is checked by predation or parasitism (30), and in locations with highly asynchronous planting, significant emigration may occur while the crop is still at the maximum tillering stage (110). In dry seasons, there tends to be a more gradual increase in leafhopper abundance in the rice crop, with peak abundance often reached when plants are senescing (30). Emigration of leafhoppers occurs as the level of nutrients available to them in rice plants declines and plants become unsuitable for oviposition $(25,31)$.

Sources of inoculum. A wide range of plants other than rice has been reported as hosts of RTSV and RTBV based on symptoms or serology $(3,64)$. However, leafhopper recovery of virus from infected weeds to rice has been very difficult to demonstrate definitively in experiments and has not been convincingly established for $N$. virescens $(64,117)$. RTBV has been detected in samples of Oryza rufipogon collected from the field, so it is likely that this and some other wild rices provide a source of inoculum in certain locations (117). Moreover, regenerated stubble and volunteer rice plants may harbor tungro viruses, and these may be important sources in some situations (117). However, in areas where tungro is endemic, it is likely that rice plants in standing crops constitute the strongest inoculum source.

Disease development. In irrigated areas with staggered plantings and strong sources of tungro infection, primary inoculum may be introduced into rice fields by viruliferous leafhopper vectors within a few days of transplanting (Fig. 3). The short latent period of infection in the plant combined with short acquisition and inoculation feeding times in the vector favor very rapid secondary spread of the disease. The establishment of leafhopper populations occurs later in transplanted than in direct-seeded fields, but the greater movement of leafhoppers in transplanted fields creates the potential for more rapid spread of tungro (62). As with many polycyclic diseases, tungro epidemics are typically well described by the logistic model. Early foci of infection expand into clusters of diseased hills, and these continue to grow before coalescing with adjacent clusters until almost all the plants may be infected (24). Late instar leafhopper nymphs, although not able to fly, can make a signifi- 
cant contribution to tungro disease development once the leaf canopy closes. In field studies conducted on the island of Bali in Indonesia, tungro incidence was significantly correlated with densities of fourth to fifth instar $N$. virescens nymphs at the vegetative stage of plant growth (109).

Early infections tend to be mainly with RTSV (115), although dual infections with RTSV and RTBV may quickly predominate where tungro disease sources are widespread (24). Survey data from five sites in the Philippines from 1995 to 1997 show that tungro disease is strongly associated with single RTSV infection, as well as with dual infections (23). Consequently, the deployment of resistance to RTSV is likely to have a significant effect in reducing disease spread, as suggested by Hibino and coworkers (51) and subsequently demonstrated in experimental plots (94). The Philippine survey showed a clear association between tungro incidence and the extent to which susceptible varieties are grown, and this finding is supported by results from a case study conducted in Albay Province, Philippines, in 1993-94 (27).

In irrigated areas with staggered rice plantings, leafhopper vectors disperse from crops at the midtillering stage to new plantings in neighboring fields (110). As there is often no clear break between cropping seasons in these locations, conditions are favorable for the persistence of tungro disease throughout the year. Several studies have demonstrated a strong association between high tungro incidence and asynchronous planting $(16,23,25,90)$. Holt and Chancellor (56) developed a mathematical model to assess the potential impact of changes in cropping synchrony for reducing tungro incidence. The outputs of the model showed that tungro endemicity was largely determined by the variance of planting dates and that disease persisted if this variance exceeded a certain threshold. Tungro incidence is usually greatest in rainy seasons, as climatic conditions are more favorable for leafhopper population development and larger areas of rice are grown than in dry seasons. In dry seasons, the greater spatial separation between plantings reduces the potential for dispersal of vectors and inoculum between fields (114). Although leafhopper vectors are capable of dispersing over longer distances, results from the case study in Albay Province, Philippines, showed that the risk of infection in a new planting that was more than $1 \mathrm{~km}$ from the disease source was very low (57).

High tungro incidence is associated with increasing vector densities, but the relationship is often complex. An analysis of survey data in Central Luzon, Philippines, where tungro occurs infrequently but outbreaks tend to be large in scale, showed that the number of viruliferous vectors was more important than absolute numbers of vectors in driving disease epidemics (95). Findings from the same survey revealed that, in two endemic areas in the Philippines, tungro was associated with both increasing vector numbers and number of viruliferous vectors. Similar results were recorded in field plots on the IRRI experimental farm where planting was staggered and disease sources were widespread (24).

Genetic structure of tungro virus populations in Southeast Asia. Development and deployment of durable resistance to tungro viruses is considered a priority for stable rice production in intensive irrigated ecosystems. Geographical variation in tungro viruses $(17,32)$ and shifts in leafhopper virulence (33) have been reported. Therefore, to complement efforts to in-

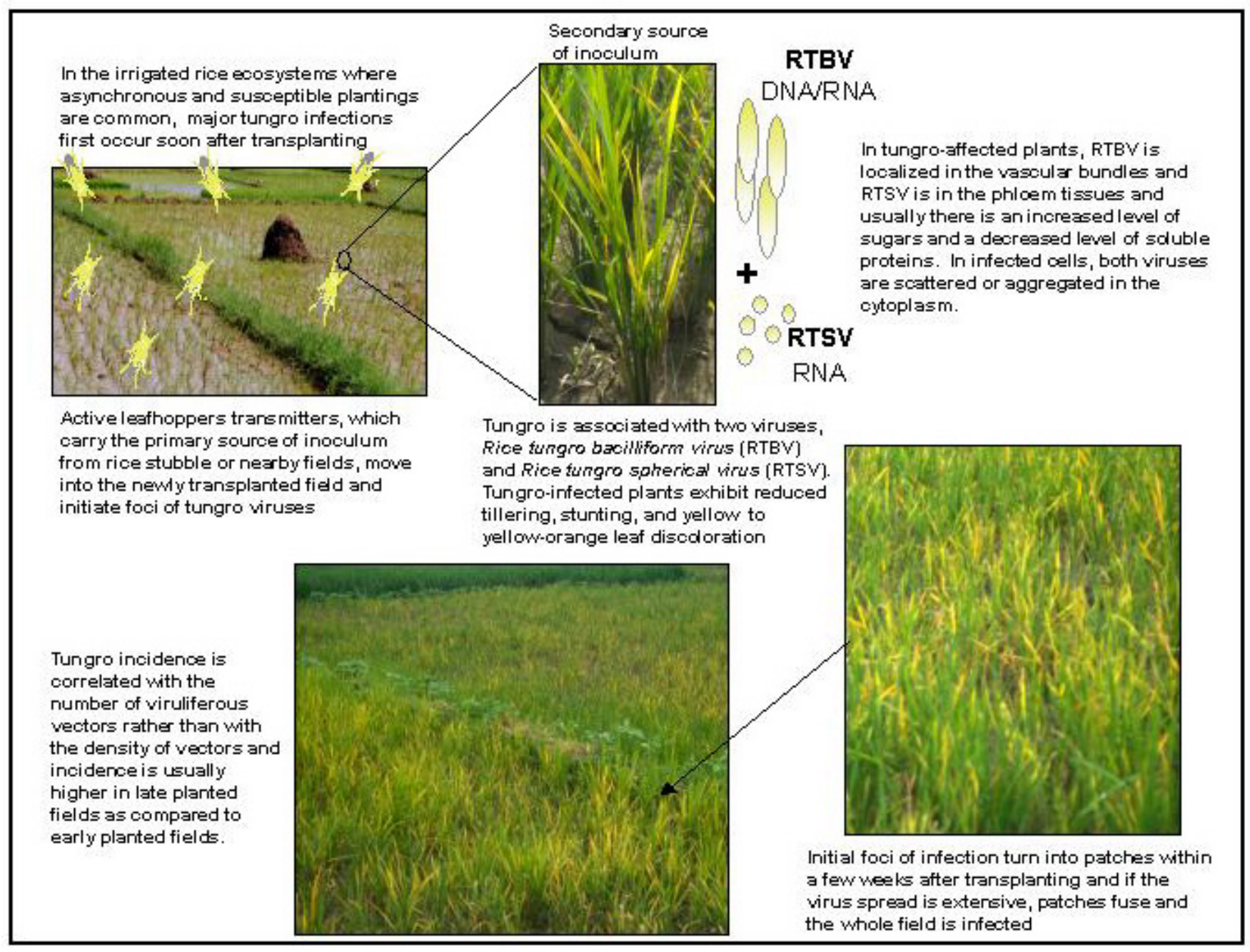

Fig. 3. Tungro disease development in the field. 

to green leafhopper at the International Rice Research Institute

\begin{tabular}{|c|c|c|}
\hline $\begin{array}{l}\text { Source of } \\
\text { resistance }\end{array}$ & Gene & Ref. \\
\hline Pankhari 203 & Glh-1a & \multirow[t]{3}{*}{5} \\
\hline ASD7 & Glh-2 & \\
\hline IR8 & Glh-3 & \\
\hline Ptb8 & glh-4 & \multirow[t]{2}{*}{103} \\
\hline ASD8 & Glh-5 & \\
\hline TAPL 796 & Glh-6 & \multirow[t]{2}{*}{86} \\
\hline Maddai Karuppan & Glh-7 & \\
\hline DV85 & glh-8 & 38 \\
\hline IR28 & Glh-9 & \multirow[t]{5}{*}{1} \\
\hline IR36 & glh-10 & \\
\hline IR20965-26-1-2 & Glh-11 & \\
\hline ARC10313 & Glh-12 & \\
\hline Asmaita & Glh-13 & \\
\hline
\end{tabular}

Table 2. Identified genes for resistance

corporate virus resistance into new IRRI varieties, Azzam and coworkers conducted a detailed analysis of the genetic structure of natural virus populations in endemic and outbreak tungro areas from 1996 to 1999. The main objective of these studies was to understand the spatial and temporal structure of virus populations that are relevant to the development of virus control strategies and to the more efficient deployment of virus resistance genes. Several hundred isolates of RTBV and RTSV were collected from the Philippines and Indonesia, and restriction fragment length polymorphism (RFLP) assay was developed and used to type them.

Results from these studies showed that both RTBV and RTSV populations were geographically isolated and stable over the period of the study with occasional shifts in response to host/environmental changes $(4,11)$. These findings suggest that targeted

Table 3. Characteristics of current sources of resistance to tungro disease available in rice germ plasm at the International Rice Research Institute

\begin{tabular}{lcccc}
\hline Accessions & RTSV-A $^{\mathbf{a}}$ & RTSV-Vt6 $^{-}$ & RTBV $^{\mathbf{b}}$ & $\begin{array}{c}\text { Nephotettix } \\
\text { virescens }\end{array}$ \\
\hline 336 & $\mathrm{R}^{\mathrm{c}}$ & $\mathrm{S}$ & $\mathrm{S}$ & $?$ \\
34 & $\mathrm{R}$ & $\mathrm{R}$ & $\mathrm{S}$ & $\mathrm{R}$ \\
18 & $\mathrm{R}$ & $\mathrm{R}$ & $\mathrm{S}$ & $\mathrm{S}$ \\
3 & $\mathrm{R}$ & $?$ & $\mathrm{~T}$ & $\mathrm{~S}$ \\
3 & $\mathrm{R}$ & $?$ & $\mathrm{~T}$ & $\mathrm{R}$ \\
\hline
\end{tabular}

${ }^{a}$ Rice tungro spherical virus (RTSV)-A refers to the avirulent strain of RTSV on the rice variety TKM6, whereas RTSV-Vt6 refers to the virulent strain on the same variety.

${ }^{\mathrm{b}}$ Rice tungro bacilliform virus.

${ }^{\mathrm{c}} \mathrm{R}=$ resistant, $\mathrm{S}=$ susceptible, $\mathrm{T}=$ tolerant, $?=$ not tested. deployment of virus resistance genes may be more effective in South than in Southeast Asia. In addition, these studies showed that within one location, genetic and biological variants may coexist, suggesting that multiple resistance may be needed in the endemic regions of tungro to increase its durability. When the population structure of both viruses was studied in the same sample, there was no correlation between the population diversity of RTBV and that of RTSV. In tungro outbreak areas, shifts in genotypic composition of RTBV and changes in RTSV gene diversity were observed from the dry to the rainy season, suggesting that shifts in the composition and/or gene diversity of either RTBV or RTSV populations may lead to rapid virus evolution and disease outbreak (7). Further studies are still needed to monitor the effects of various environmental factors and genetics of the rice host on the population structure of both viruses, in areas where virus resistance is deployed.

\section{Management Strategies for Rice Tungro Disease}

Forecasting tungro outbreaks. The unpredictability of a disease outbreak and the risk of a major crop loss in intensive irrigated ecosystems, where rice is grown continuously and asynchronously throughout the year, induced researchers to study epidemiological factors that are critical in predicting early tungro infection in the field. In Malaysia, a pest surveillance and forecasting system was established for rice growing areas by the Department of Agriculture in 1979, and considerable resources

Table 4. Selection and breeding process for tungro resistance as practiced at the International Rice Research Institute in the Philippines

\begin{tabular}{|c|c|}
\hline Steps & Assay used \\
\hline $\begin{array}{l}\text { 1. Mass screening of rice germ plasm using } \\
\text { viruliferous leafhoppers and doubly infected } \\
\text { plants (RTBV + RTSV) as disease source }\end{array}$ & $\begin{array}{l}\text { Symptom scoring using IRRI } \\
\text { standard evaluation system }\end{array}$ \\
\hline $\begin{array}{l}\text { 2. Forced-tube insect inoculation of young rice } \\
\text { seedlings using selected lines with low } \\
\text { symptom scores and doubly infected plants } \\
\text { (RTBV + RTSV) as disease source }\end{array}$ & $\begin{array}{l}\text { DAS-ELISAc using RTBV- and } \\
\text { RTSV-specific antibodies, restriction } \\
\text { endonuclease profiles, polymerase } \\
\text { chain reaction, and Southern blotting }\end{array}$ \\
\hline
\end{tabular}

3. Seed box test for evaluating level of resistance to green leafhopper vector 4. Crossing tungro resistance source with improved plant line and inoculation of F1 seeds with doubly infected plants (RTBV + RTSV) as disease source

5. Field evaluation of F2 and F3 populations using natural virus populations and/or greenhouse virus populations

6. Evaluation of backcrossed lines (4-5 times) or selected F5/F6 lines by insect inoculation
Plant damage is estimated based on IRRI standard evaluation system DAS-ELISA using RTBV- and RTSV-specific antibodies

Symptom scoring using IRRI standard evaluation system

DAS-ELISA using RTBV and RTSV specific antibodies

\section{Purpose}

Eliminates very susceptible accessions

Separates RTBV resistance from RTSV resistance

Entries with RTSV infection of less than $10 \%$ will be retested using RTSV alone (different strains as a disease source) to confirm the resistance and identify its type

Entries with RTBV infection less than $30 \%$ are retested using RTBV alone and agroinoculation assay to confirm the resistance

Helps in differentiating insect resistance from virus resistance

Ensures the transfer of virus resistance

Allows screening for multiple disease resistance

Ensures maintenance of virus resistance prior to yield evaluation trials in the field

${ }^{a} \mathrm{RTBV}=$ Rice tungro bacilliform virus; $\mathrm{RTSV}=$ Rice tungro spherical virus .

b International Network for Genetic Evaluation of Rice (INGER). 1996. Standard Evaluation System for Rice. 4th ed. Los Baños, Laguna. International Rice Research Institute (IRRI).

${ }^{\mathrm{c}}$ Double-antibody sandwich enzyme-linked immunosorbent assay. 
are still invested in it (82). As part of this system, field scouting is conducted for tungro and leafhopper vectors. This is combined with a network of mobile nurseries to detect the presence of tungro virus infection through the use of leafhopper transmission tests and, more recently, ELISA. Once threshold numbers of vectors and infection rates have been exceeded, this information is relayed to agricultural extension officers and farmers through an established communication system. In this situation, the application of an insecticide is recommended, but in many cases interventions can be restricted to relatively small areas.

Moreover, in the early 1990s, Suzuki and coworkers examined the potential for developing a disease forecasting system by monitoring the spread of tungro and studying the population dynamics of $N$. virescens in Bali, Indonesia, an endemic region for tungro. Using regression analyses, they demonstrated that the incidence of tungro infection at a given time was largely dependent on both the newly infected area a month earlier and the amount of rice planted 3 months earlier (109). No forecasting system has been implemented following this work, possibly due to the lack of resources to collect the required data and the constraints to the adoption of an appropriate disease management strategy.

Cultural control measures. A range of cultural practices has been recommended for control of tungro disease. The use of large-scale synchronous planting with a distinct fallow period between cropping seasons has been widely advocated since the work of Loevinsohn (72). The aim of this approach is to eradicate virus sources and to reduce densities of immigrant vector populations. The adoption of these practices has been successful in controlling tungro disease in South Sulawesi, Indonesia (90) and in Sabah, Malaysia (65). Modeling studies have suggested that where planting dates are only moderately asynchronous, relatively small reductions in planting date variance can have a significant effect in reducing tungro incidence (56). Unfortunately, implementing changes on even this limited scale in tungro endemic areas can be very difficult due to various socio-economic and socio-cultural constraints. Moreover, synchronous planting may not always be appropriate for the management of other pest problems, as the carryover of natural enemies between crops is also reduced (122). For these reasons, areas with highly staggered rice transplanting such as Mindanao, Philippines, and Bali and Central Java, Indonesia, persist and continue to host major tungro outbreaks.

In many areas, the risk of tungro incidence is greatest in late plantings as infection builds up in earlier planted crops $(24,100)$. Therefore, the avoidance of late planting is recommended in such situa- tions. However, as with synchronous planting and fallow periods, it is often difficult for farmers to follow these recommendations due to such factors as lack of water or the absence of credit to buy inputs at the appropriate time (121).

Elimination of disease sources by roguing, the removal of plants showing symptoms, is recommended in some countries for tungro control. However, field trials showed that roguing was only effective under low disease pressure and that it is not therefore a practical management strategy (116). Simulation modeling also suggested that, for roguing to be successful, the required frequency and efficiency of removal of diseased plants is not feasible (55). Manipulation of plant spacing is another practice that has been recommended for improved tungro control. In transplanted crops, closer spacing was shown to result in reduced tungro incidence (101). The expanding area of direct-seeded rice in some areas, primarily due to shortages of labor for transplanting, may also have an effect in reducing tungro incidence (62). Greater plant densities in direct-seeded rice restrict leafhopper movement and reduce the probability that vectors will encounter diseased plants that act as a source for further spread.

Control of the vector with insecticides. In many countries where tungro is prevalent, farmers commonly apply highly toxic broad-spectrum insecticides that are directed at a range of pests (45). Efficacy for tungro management is generally low, and spray operations present a serious hazard to operator health. Nevertheless, much of the early research on tungro involved evaluating the effectiveness of different insecticides for controlling $N$. virescens. The use of insecticide was widely seen as an integral component of a package of inputs needed to successfully cultivate the modern varieties, and this view was reinforced with the occurrence of major outbreaks of the rice brown planthopper, Nilaparvata lugens (Stål). Calendar spraying of insecticides was recommended in most countries where the varieties were adopted, sometimes with up to six applications irrespective of the level of insect pest infestation (113). Against this background, the socalled breakdown in resistance of the leafhopper-resistant varieties led to an increased dependency on insecticides. Many greenhouse and field studies have been conducted to evaluate the efficacy of a wide range of insecticides using different intervention strategies $(26,43)$.

In general, foliar insecticide applications that rely on contact action and that have low persistency have limited effect in reducing tungro incidence. An exception is the synthetic pyrethroid cypermethrin, which has a rapid knockdown effect, but successful control requires frequent applications (91). Cypermethrin has been shown, however, to induce resurgence of
$N$. lugens and so has limitations for tungro control (98). Newer compounds such as imidacloprid have been evaluated for efficacy against Nephotettix spp. (79), but these are not yet widely available for use by subsistence rice farmers in Asia. Chemical application in trap crops has been proposed to overcome some of these constraints (96), but this approach has not been widely adopted by farmers. The use of granular applications to protect healthy crops from primary infection with tungro has been advocated by some researchers. Compounds such as carbofuran and isoprocarb were shown to be most effective in reducing tungro infection because of their rapid activity and long persistence (92). Application of granular insecticides to the root zone gave better control than broadcasting in field trials due to the more efficient uptake of the chemical and the slower rate of degradation (93). However, an appropriate application technology for root zone application has not been developed, and broadcasting carbofuran granules in the field is not economically viable (44).

In order to avoid the undesirable effects of synthetic compounds, researchers have examined the potential of oils and other plant extracts to control leafhopper vectors. Oils extracted from seeds of neem, Azadirachta indica, and custard apple, Annona squamosa, have been evaluated in several formulations. Neem has both antifeedant and insecticidal properties and has shown good control of tungro in field trials when incorporated into the soil (97). However, application of neem and other botanical products is not widely practiced for tungro control.

Conventional host-plant resistance. IRRI hosts more than 80,000 accessions of rice, of which at least one-third have been screened since 1963 to identify sources of resistance to tungro using various methods $(8,52,66)$. Because vector resistance was abundant and easily identified in the germ plasm, most of the IR varieties released after 1969, except for IR22, were rated as leafhopper-resistant at the time they were released. The main donors have been Ptb18, Gam Pai 30-12-15, and Ptb33. Unfortunately, this type of resistance was not sustainable in the field under high disease pressure, and in many cases, varieties with vector resistance succumbed to tungro infection soon after their release $(33,73)$. Consequently, although several additional sources of leafhopper resistance have been identified in the past few years (Table 2), the focus has shifted to identifying and utilizing tungro virus resistance (Table 3). In addition, several genetic studies have been conducted to understand the inheritance of virus resistance $(9,61)$.

Screening for tungro virus resistance at IRRI is feasible due to the availability of serological tests such as DAS-ELISA that allow for the differentiation between RTBV and RTSV resistance (13) and the 
availability of an agroinoculation technique that enables RTBV resistance to be identified independently of RTSV or green leafhopper resistance (106). Tables 2 and 3 show an updated list of the sources of resistance that are available at IRRI and summarize the screening of most of the germ plasm that is derived from Bangladesh, India, Indonesia, Sri Lanka, and Pakistan in addition to some wild rice species (O. Azzam, F. Sta. Cruz, E. Coloquio, and R. Cabunagan, unpublished). A large number of accessions are resistant to the most common strain of RTSV, RTSV-A, and 34 accessions are resistant to both RTSV-A and RTSV-6. No sources of true resistance to RTBV have yet been identified, but six accessions have been found to show tolerance to infection. Table 4 outlines the screening and selection process for tungro resistance as practiced at IRRI, and Table 5 shows the sources of resistance that are currently being used in the breeding program. Since most of the sources of resistance to the virus have poor plant type, it was necessary to transfer the genes for virus resistance into lines with improved morphology by crossing and selecting segregants with resistance to the virus. The selected lines were then evaluated for two or three generations for plant type, grain quality, and resistance traits (8).

The recent advanced breeding lines derived from Balimau Putih, Utri Merah, ARC 11554, Habiganj DW8, $O$. longistaminata, and O. rufipogon (Table 6) were evaluated from 1995 to 1998 in the Philippines, Indonesia, and India. IR62 and IR64 were used as field-resistant and susceptible checks, respectively. Results revealed that the most promising advanced breeding lines were two accessions derived from Utri Merah, IR 69705-1-1-3-2-1 and IR69726-116-1-3, which have resistance to RTSV and tolerance to RTBV (22). These lines showed consistently low infections with both RTBV and RTSV across all locations (Fig. 4). The results demonstrate that virus resistance derived from Utri Merah is effective and could easily be combined with additional vector resistance to help ensure that it is durable. Meanwhile, some of the most promising virus-resistant lines have already been released as varieties in Indonesia. In 1998, line IR69726-116-1-3 was released under the name Tukad petanu and performed well in Bali, East Java, and Lombok. Line IR68305-18-1, with tolerance to RTBV derived from Balimau Putih, was especially attractive to farmers because of its good eating quality and desirable plant type. This line has been released in Indonesia as Tukad unda and was being cultivated on more than 10,000 ha in Bali in 1999 with no reports of tungro infection (Mahyuddin Syam, personal communication). Selected lines are also scheduled for release in the Philippines and are being utilized in resistance breeding programs in India.
Transgenic virus resistance. Following the demonstration of genetically engineered resistance to virus in various crop species $(36,42,108)$ using the coat-protein mediated protection strategy, several institutes were interested in using antiviral strategies to combat tungro in Asia. Using conventional breeding, the process of incorporating virus resistance by pedigree and backcross methods in multiple pest and disease resistance programs, is labor-intensive and time-consuming, and it is difficult to predict that the final product would confer durable resistance. In addition, breeders need to select for many other characteristics, and if tungro virus resistance genes were linked to undesirable traits, then the process would be more complex. These considerations stimulated considerable interest in the transgenic approach, which was seen as having the capacity to provide a broad spectrum and durable forms of resistance if basic steps in viral replication or movement could be identified and blocked.

Table 7 summarizes the different antiviral strategies that have been attempted to develop resistance to tungro. Rice varieties IR64, TN1, Taipei 309, and Kinuhikari have been successfully transformed with the various expression vectors, and fertile transgenic plants were evaluated at $\mathrm{T} 1, \mathrm{~T} 2$, and in some cases at $\mathrm{T} 3$ and $\mathrm{T} 4$ generations for their ability to confer protection against tungro disease and/or its individual virus components. RTBV coat protein, polymerase, protease, RNase $\mathrm{H}$, and antisense RNA resistance strategies were attempted against RTBV infection using both Cauliflower mosaic virus (35S) and RTBV promoters. The three coat protein genes and the polymerase (sense and antisense) strategies were tried against RTSV using $35 \mathrm{~S}$ and ubiquitin promoters. Seeds from each transgenic line were sown, and 7- to 14-day-old seedlings were inoculated either with both tungro viruses (10) or with RTSV alone $(58,102)$ by insect feeding using three to five viruliferous green leafhoppers per seedling.

Unfortunately, the resistance tests showed that none of the RTBV resistance strategies was effective in reducing or preventing tungro infection (10). The irregular expression of various integrated RTBV transgenes could account for the lack of resistance. Therefore, new transgeneexpression strategies have been designed, and the newly transformed plants will be evaluated soon. For RTSV, however, near

Table 5. Characteristics of the current sources of resistance to tungro disease that are being used by the breeding program at the International Rice Research Institute

\begin{tabular}{lccc}
\hline Source of resistance & RTSV $^{\mathbf{a}}$ & RTBV & Nephotettix virescens \\
\hline ARC 11554 & $\mathrm{R}^{\mathrm{b}}$ & $\mathrm{T}$ & $\mathrm{R}$ \\
Oryza rufipogon & $?$ & $\mathrm{~T}$ & $\mathrm{R}$ \\
O. officinalis & $?$ & $\mathrm{~T}$ & $\mathrm{R}$ \\
O. longistaminata & $?$ & $\mathrm{~T}$ & $\mathrm{R}$ \\
Balimau Putih & $\mathrm{S}$ & $\mathrm{T}$ & $\mathrm{S}$ \\
Utri Merah (16680) & $\mathrm{R}$ & $\mathrm{T}$ & $\mathrm{S}$ \\
Utri Merah (16682) & $\mathrm{R}$ & $\mathrm{T}$ & $\mathrm{S}$ \\
TKM6 & $\mathrm{R}$ to RTSV-A & $\mathrm{S}$ & $\mathrm{S}$ \\
Adday Selection & $\mathrm{R}$ to RTSV-Vt6 & $\mathrm{S}$ & $\mathrm{S}$ \\
Habiganj DW8 & $\mathrm{R}$ & $\mathrm{S}$ & $\mathrm{S}$ \\
Utri Rajapan & $\mathrm{R}$ & $\mathrm{S}$ & $\mathrm{S}$ \\
\hline
\end{tabular}

${ }^{\bar{a}} \mathrm{RTSV}=$ Rice tungro spherical virus; $\mathrm{RTBV}=$ Rice tungro bacilliform virus. $\mathrm{RTSV}$-A refers to the avirulent strain of RTSV on the rice variety TKM6, whereas RTSV-Vt6 refers to the virulent strain on the same variety.

${ }^{\mathrm{b}} \mathrm{R}=$ resistant, $\mathrm{S}=$ susceptible, $\mathrm{T}=$ tolerant, ? = difficult to distinguish from resistance to the vector.

Table 6. Newly advanced breeding lines that have been tested recently in the Philippines, Indonesia, and India

\begin{tabular}{ll}
\hline Breeding line & Cross \\
\hline IR68305-18-1 & IR64*4/Balimau Putih \\
IR69705-1-1-3-2-1 & IR1561-228-3-3*2/Utri Merah \\
IR69726-16-3-2 & IR61009-37-2-1-2/// IR1561-228-3-3/Utri Merah//IR1561 \\
IR69726-116-1-3 & IR61009-37-2-1-2/// IR1561-228-3-3/Utri Merah//IR1561 \\
IR69734-5-1-2 & IR44624-127-1-2-2-3/// IR1561-228-3-3/Utri Merah//IR1561 \\
IR69734-128-2-3 & IR44624-127-1-2-2-3/// IR1561-228-3-3/Utri Merah//IR1561 \\
IR71026-3-2-4-3-5-2 & IR1561-228-3-3*2/Oryza longistaminata \\
IR71030-2-3-2-1 & IR1561-228-3-3*6/ARC11554 \\
IR71031-4-5-5-1 & IR1561-228-3-3*6/ARC11554 \\
IR71605-2-1-5-3 & IR1561-228-3-3*3/Habiganj DW8//4*IR64 \\
IR73890-1-3-1-4-1 & IR1561-228-3-3*2/Utri Merah//IR24 \\
IR73891-2-1-5-1 & IR64/Oryza rufipogon//3*IR64 \\
\hline
\end{tabular}


immunity against the virus was achieved in transgenic rice plants when the entire or truncated part of the replicase gene was used (58). Replicase-mediated resistance is more limited to closely related isolates, but this strategy will be evaluated against different RTSV variants. If this approach proves to be effective, the breeders will have another option to incorporate tungro virus resistance.

\section{Future Prospects}

Although rice tungro outbreaks are now less frequent in synchronized irrigated rice areas, the disease remains a key production constraint in India, Indonesia, and the Philippines, where its sporadic occurrence continues to have devastating effects on many subsistence farm communities. Successful tungro management strategies have been developed and implemented in locations where irrigation water can be controlled and where governments have been able to coordinate control programs over large areas $(65,90)$. In areas where staggered planting remains the norm, solutions to the tungro problem are more problematic. Recent epidemiological research has greatly enhanced our understanding of tungro dynamics, but suitable disease management options are limited. The expansion of the area of rice that is established by direct seeding may help to reduce the intensity of tungro outbreaks, but further research is needed to clearly establish the potential of direct seeding for reducing the spread of tungro disease. Moreover, direct seeding cannot be implemented in all areas, as it requires good control of irrigation water and field drainage. Chemical interventions are usually inappropriate, as these are often ineffective and they threaten to undermine the new paradigm for integrated pest management in rice that has gained increasing recognition in recent years (76).

Given the limitations of cultural and chemical methods of control under these conditions, the development and deployment of resistant varieties offers the best hope for improved control. Although the development of resistant varieties incurs significant research costs, varietal resistance is a relatively cheap and easy option for farmers to use provided appropriate seed is readily available. Unfortunately, there are shortcomings in seed production and distribution systems in many ricegrowing countries in Asia, so that farmers do not always have access to the most suitable varieties. Greater decentralization of breeding programs and participation of farmers in plant breeding help to overcome these constraints and are beginning to have an impact in some countries (124). Support for such initiatives needs to be intensified in the future.

The rapid adoption of the new tungro virus resistant varieties in parts of Indonesia suggests that there is a strong demand by farmers for these varieties, and there have been no reports of any tungro disease from fields where they have been grown. The utilization of resistance to RTSV that is effective against both RTSV-A and RTSVVt6, combined with tolerance to RTBV in one of these varieties, is considered to strengthen the durability of resistance in the field. Although there are grounds for optimism, the recent findings that tungro virus populations in the field are heterogeneous, and that the balance of variants shifts between seasons, suggests that strong selection pressure could lead to a breakdown in resistance. Thus, the situation in Indonesia needs to be carefully monitored in order to identify whether any tungro virus variants evolve that threaten

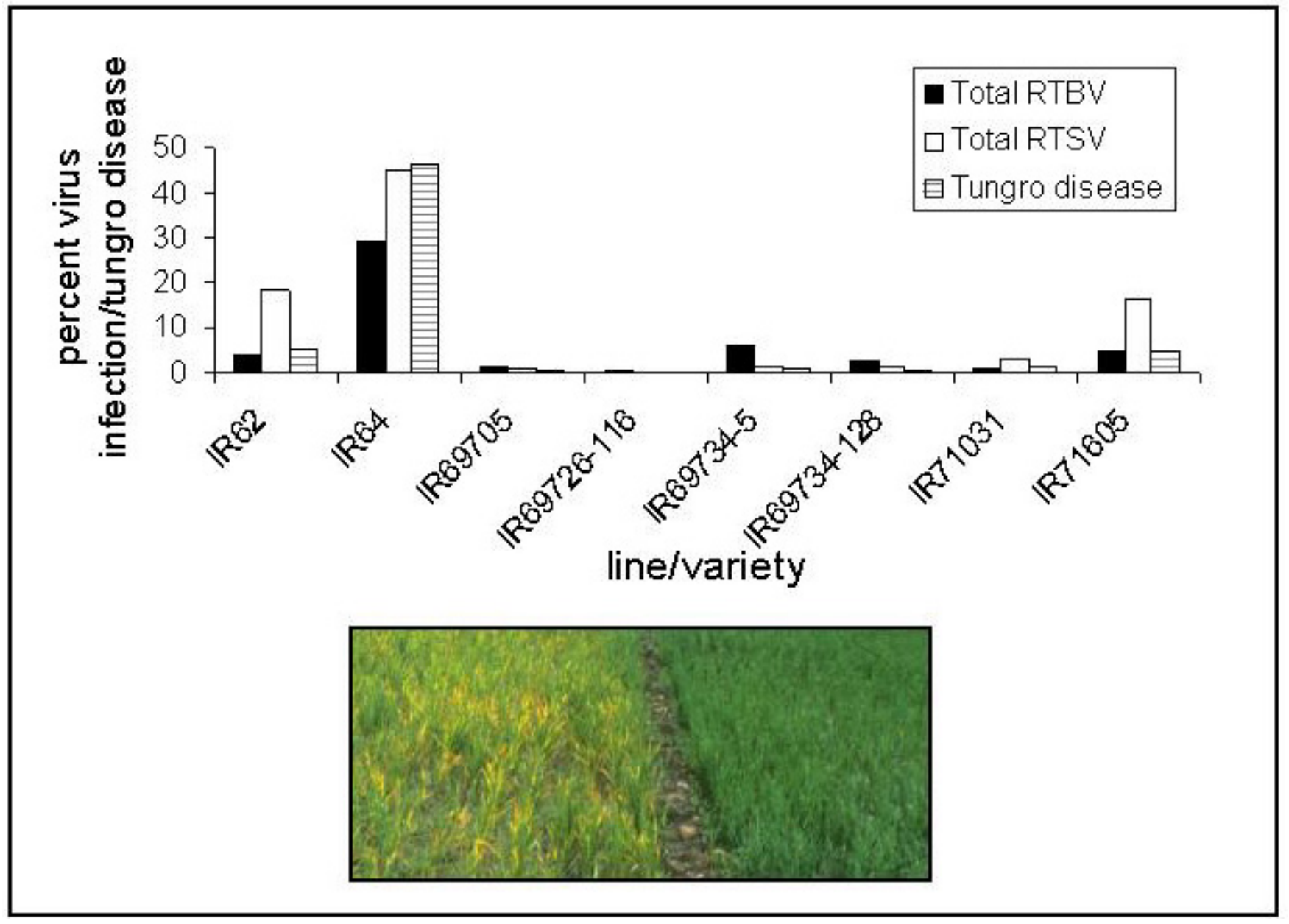

Fig. 4. Mean infection with Rice tungro bacilliform virus (RTBV) and Rice tungro spherical virus (RTSV) and tungro disease incidence in the field trials of the advanced breeding lines that were developed at the International Rice Research Institute and evaluated in India, Indonesia, and Philippines between 1995 and 1998 . The picture below shows a comparison between a susceptible rice crop (IR64) and a resistant rice crop (IR69726-116). 
the success of the current deployment strategy. Such research should also be directed at investigating the mechanism of virus evolution in the field so that the most appropriate virus resistance strategies can be employed.

There are many sources of resistance to $N$. virescens that can be exploited in breeding programs (1). Although leafhopper adaptation to varieties carrying some resistance genes has occurred among field populations, some resistance genes are still effective (22). Advances in nonconventional breeding approaches, particularly with the RTSV replicase-antiviral approach, enhance the prospects for achieving durable resistance to tungro in the near future. As the transgenic approaches join hands with conventional breeding, it is likely that the development of tungro resistant varieties with broader specificity will be accelerated. Because of public concern with the use of viral genes as transgenes $(75,80)$, transgenic approaches may not be limited to viral genes. The recent advances in genomic research and plant molecular biology should allow us to incorporate novel genes that resist not only viruses but also a diverse range of other pathogens or vectors. Indeed, several natural host resistance genes, genes encoding PR proteins, genes against insect vectors, and antiviral gene products have recently been identified $(39,60)$ and are being explored as potential broad-spectrum resistance. Breeding of varieties with such genes will be accelerated since defense gene segregation will be easily assayed using a DNA probe instead of testing each progeny for its susceptibility or resistance to a particular pathogen.
In conclusion, over the past three decades our increased understanding of the biology and epidemiology of rice tungro has led to the development of more targeted strategies for the management of the disease. This has been made possible through a combination of strategic and applied research and the involvement of multidisciplinary teams including rice breeders, virologists, entomologists, modelers, social scientists, extensionists, and farmers. Institutional partnerships both within and between countries in South and Southeast Asia have been important in facilitating the flow of information and ensuring that the research has genuine impact at the farmer level. Although tungro remains a problem in several countries, there is an increasingly wider array of resistance management options, and it is hoped that these will form the basis for effective and durable management strategies for this complex disease.

\section{Acknowledgments}

We thank F. C. Sta. Cruz for the electron micrographs of RTBV and RTSV virions and the pictures of tungro symptoms with the leafhopper vector. The authors are also grateful to Mike Thresh for his critical review of the manuscript. Both authors acknowledge the support and encouragement of their respective institutes in the production of this manuscript.

\section{Literature Cited}

1. Angeles, E. R., and Khush, G. S. 2000. Genetic analysis of resistance to green leafhopper, Nephotettix virescens (Distant) in three varieties of rice. Plant Breed. 119(5):446448.

2. Anjaneyulu, A., Satapathy, M. K., and Shukla, V. D. 1994. Rice Tungro. Oxford \& IBH, New Delhi, India.
3. Anjaneyulu, A., Shukla, V. D., Rao, G. M. and Singh, S. K. 1982. Experimental host range of rice tungro virus and its vectors. Plant Dis. 66:54-56.

4. Arboleda, M., and Azzam, O. 2000. Interand intra-site genetic diversity of natural field populations of rice tungro bacilliform virus in the Philippines. Arch. Virol. 145:275-289.

5. Athwal, D. S., Pathak, M. D., Bacalangco, E. H., and Pura, C. D. 1971. Genetics of resistance to brown planthoppers and green leafhoppers in Oryza sativa L. Crop Sci. 11:747750

6. Auclair, J. L., Baldos, E., and Heinrichs, E. A. 1982. Biochemical evidence for the feeding sites of the leafhopper, Nephotettix virescens within susceptible and resistant rice plants. Insect Sci. Appl. 3:29-34.

7. Azzam, O., Arboleda, M., Umadhay, K., De Los Reyes, J., Sta. Cruz, F., Mackenzie, A., and McNally, K. 2000. Genetic composition and complexity of virus populations at tungro-endemic and outbreak rice sites. Arch. Virol. 145:2643-2657.

8. Azzam, O., Cabunagan, R., and Chancellor, T. C. B., eds. 2000. Methods for Evaluating Resistance to Rice Tungro Disease. IRRI Discussion Paper Series No. 38. International Rice Research Institute, Makati City Philippines.

9. Azzam, O., Imbe, T., Ikeda, R., Nath, P. D. and Coloquio, E. 2001. Inheritance of resistance to rice tungro spherical virus in a near isogenic line derived from Utri Merah and in TKM6 rice cultivar. Euphytica 122(1):89-95.

10. Azzam, O., Klöti, A., Sta. Cruz, F., Fütterer, J., Coloquio, E. L., Potrykus, I., and Hull, R. 1999. Genetic engineering of rice for tungro resistance. Pages 39-44 in: Proc. Workshop Rice Tungro Dis. Manag. T. C. B. Chancellor, O. Azzam, and K. L. Heong, eds. 9-11 November 1998. Los Baños, Philippines.

11. Azzam, O., Yambao, Ma, L. M., Muhsin, M., McNally, K., and Umadhay, K. 2000. Genetic diversity of rice tungro spherical virus in tungro-endemic provinces of the Philippines and Indonesia. Arch. Virol. 145:1183-

Table 7. Attempted transgenic approaches to control rice tungro disease caused by Rice tungro bacilliform virus (RTBV) and Rice tungro spherical virus (RTSV)

\begin{tabular}{|c|c|c|c|c|}
\hline $\begin{array}{l}\text { No. of } \\
\text { transformants }\end{array}$ & Promoters & Gene or gene combinations used in expression vector & Variety & Reference \\
\hline 3 & $\begin{array}{l}35 \mathrm{~S} \\
\text { RTBV }\end{array}$ & Open reading frame 1 of RTBV & $\begin{array}{l}\text { Taipei } 309 \\
\text { (TP309) }\end{array}$ & 10 \\
\hline 6 & $\begin{array}{l}35 \mathrm{~S} \\
\text { RTBV }\end{array}$ & Combination of RTBV coat protein region & ТР309 & \\
\hline 3 & $\begin{array}{l}35 S \\
\text { RTBV }\end{array}$ & Polymerase & ТР309 & \\
\hline 1 & $35 \mathrm{~S}$ & Protease & ТР309 & \\
\hline 2 & $35 \mathrm{~S}$ & RNase H & TP309 & \\
\hline 4 & RTBV & Combination of RTBV open reading frame 4 & Kinuhikari & \\
\hline 5 & $35 \mathrm{~S}$ & $\begin{array}{l}\text { RTBV antisense RNA to viral transcript at tRNA binding } \\
\text { site coupled with ribozyme }\end{array}$ & IR64 & \\
\hline 5 & $\begin{array}{l}35 \mathrm{~S} \\
35 \mathrm{~S}+\text { Ubiquiton }+ \text { intron }\end{array}$ & $\begin{array}{l}\text { RTBV antisense RNA to viral transcript at tRNA binding } \\
\text { site }\end{array}$ & IR64 & \\
\hline 3 & $35 \mathrm{~S}+$ Ubiquiton + intron & RTSV-coat protein 3 & IR64 & \\
\hline 1 & Ubiquiton & RTSV-coat protein 3 & TP309 & \\
\hline 7 & $\begin{array}{l}35 \mathrm{~S}+ \\
\text { Ubiquiton + intron } \\
\text { Ubiquiton + Ubiquiton + intron }\end{array}$ & $\begin{array}{l}\text { Combination of RTBV antisense RNA to viral transcript } \\
\text { at tRNA binding site and RTSV-coat protein } 3\end{array}$ & IR64 and TN1 & \\
\hline 5 & Ubiquiton + intron & RTSV-coat protein 1 & TN1 + TP309 & 102 \\
\hline 4 & Ubiquiton + intron & RTSV-coat protein 2 & $\mathrm{TN} 1+\mathrm{TP} 309$ & \\
\hline 4 & Ubiquiton + intron & RTSV-coat protein 3 & ТР309 & \\
\hline 6 & Ubiquiton + intron & Combination of RTSV-coat proteins & TP309 & \\
\hline 6 & Ubiquiton + intron & Combination of RTSV-polymerase & ТР309 & 58 \\
\hline
\end{tabular}


1197

12. Bajet, N. B., Aguiero, V. M., Daquioag, R. D., Jonson, G. B., Cabunagan, R. C., Mesina, E. M., and Hibino, H. 1986. Occurrence and spread of rice tungro spherical virus in the Philippines. Plant Dis. 70:971-973.

13. Bajet, N. B., Daquioag, R. D., and Hibino, H. 1985. Enzyme-linked immunosorbent assay to diagnose tungro. J. Plant Prot. Trop. 2:125-129.

14. Baria, A. R. 1997. Status of rice tungro disease in the Philippines: A guide to current and future research. Pages 76-83 in: Epidemiology and Management of Rice Tungro Disease. T. C. B. Chancellor and J. M. Thresh, eds. Natural Resources Institute, Chatham, UK.

15. Bottenberg, H., Litsinger, J. A., Barrion, A. T., and Kenmore, P. E. 1990. Presence of tungro vectors and their natural enemies in different rice habitats in Malaysia. Agric. Ecosyst. Environ. 31:1-15.

16. Bottenberg, H., Litsinger, J. A., Barrion, A. T., and Kenmore, P. E. 1990. Impact of cropping intensity and asynchrony on the epidemiology of rice tungro virus in Malaysia. J. Plant Prot. Trop. 7:103-116.

17. Cabauatan, P. Q., Cabunagan, R. C., and Koganezawa, H. 1995. Biological variants of rice tungro viruses in the Philippines. Phytopathology 85:77-81.

18. Cabauatan, P. Q., and Hibino, H. 1988. Isolation, purification, and serology of rice tungro bacilliform and rice tungro spherical viruses. Plant Dis. 72:526-528.

19. Cabauatan, P. Q., Kobayashi, N., Ikeda, R., and Koganezawa, H. 1993. Oryza glaberrima: An indicator plant for rice tungro spherical virus. Int. J. Pest Manag. 39:273276.

20. Cabauatan, P. Q., and Koganezawa, H. 1997. Alternative diagnostic methods for detection of rice tungro viruses. Pages 1-4 in: Epidemiology and Management of Rice Tungro Disease. T. C. B. Chancellor and J. M. Thresh, eds. Natural Resources Institute, Chatham, UK.

21. Cabauatan, P. Q., Melcher, U., Ishikawa, K., Omura, T., Hibino, H., Koganezawa, H., and Azzam, O. 1999. Sequence changes in six variants of rice tungro bacilliform virus and their phylogenetic relationships. J. Gen. Virol. 80(8):2229-2237.

22. Cabunagan, R. C., Angeles, E. R., Villareal, S., Azzam, O., Teng, P. S., Khush, G., Chancellor, T. C. B., Tiongco, E. R., Truong, X. H., Mancao, S., Astika, I. G. N., Muis, A., Chowdhury, A. K., Narasimhan, V., Ganapathy, T., and Subramanian, N. 1999. Multilocation evaluation of advanced breeding lines for resistance to rice tungro viruses. Pages 45-57 in: Proc. Workshop Rice Tungro Dis. Manag. T. C. B. Chancellor, O. Azzam, and K. L. Heong, eds. 9-11 November 1998. Los Baños, Philippines.

23. Cabunagan, R. C., Castilla, N., Colloquio, E. L., Tiongco, E. R., Truong, X. H., Fernandez, J., Du, M. J., Zarargosa, B., Hozak, R. R., Savary, S., and Azzam, O. 2001. Synchrony of planting and proportions of susceptible varieties affect rice tungro disease epidemics in the Philippines. Crop Prot. 20:499-510.

24. Chancellor, T. C. B., Cook, A. G., and Heong, K. L. 1996. The within-field dynamics of rice tungro disease in relation to the abundance of its major leafhopper vectors. Crop Prot. 15(5):439-449.

25. Chancellor, T. C. B., Cook, A. G., Heong, K. L., and Villareal, S. 1997. The flight activity and infectivity of the major leafhopper vectors (Hemiptera: Cicadellidae) of rice tungro viruses in an irrigated rice area in the Philippines. Bull. Entomol. Res. 87:247-258.
26. Chancellor, T. C. B., Heong, K. L., and Cook, A. G. 1997. Role of vector control in management of rice tungro disease. Pages 42-53 in: Epidemiology and Management of Rice Tungro Disease. T. C. B. Chancellor and J. M. Thresh, eds. Natural Resources Institute, Chatham, UK.

27. Chancellor, T. C. B., Tiongco, E. R., Holt, J., Villareal, S., and Teng, P. S. 1999. The influence of varietal resistance and synchrony on tungro incidence in irrigated rice ecosystems in the Philippines. Pages 121-127 in: Proc. Workshop Rice Tungro Dis. Manag. T. C. B. Chancellor, O. Azzam, and K. L. Heong, eds. 9-11 November 1998. Los Baños, Philippines.

28. Chen, Y. M., and Othman, A. B. 1991. Tungro in Malaysia. MAPPS Newsl. 15(1):5-6.

29. Cheng, C. H., and Pathak, M. D. 1971. Bionomics of the rice green leafhopper, Nephotettix impicticeps Isihara. Philipp. Entomol. 2:67-74.

30. Cook, A. G., and Perfect, J. 1989. Population dynamics of three leafhopper vectors of rice tungro viruses, Nephotettix virescens (Distant), N. nigropictus (Stål) and Recilia dorsalis (Motschulsky) (Hemiptera: Cicadellidae), in farmers' fields in the Philippines. Bull. Entomol. Res. 79:437-451.

31. Cooter, R. J., Winder, D., and Chancellor, T. C. B. 2000. Tethered flight activity of Nephotettix virescens (Hemiptera: Cicadellidae) in the Philippines. Bull. Entomol. Res. 90:49-55.

32. Dahal, G., Dasgupta, I., Lee, G., and Hull, R. 1992. Comparative transmission of, and reaction to, three isolates of rice tungro virus disease. Ann. Appl. Biol. 120:287-300

33. Dahal, G., Hibino, H., Cabunagan, R. C., Tiongco, E. R., Flores, Z. M., and Aguiero, V. M. 1990. Changes in cultivar reaction to tungro due to changes in "virulence" of the leafhopper vector. Phytopathology 80:659665.

34. Daradjat, A. A., Widiarta, N., and Hasanuddin, A. 1999. Breeding for rice tungro resistance in Indonesia. Pages 31-37 in: Proc. Workshop Rice Tungro Dis. Manag. T. C. B. Chancellor, O. Azzam, and K. L. Heong, eds. 9-11 November 1998. Los Baños, Philippines.

35. Dey, M. M., Miah, M. N. I., Mustsfi, B. A. A., and Hossain, M. 1996. Rice Research in Asia: Progress and Priorities. R. E. Evenson, R. W. Herdt, and M. Hossain, eds. Commonwealth Agricultural Bureau International, Wallingford, UK. pp. 179-192.

36. Dinant, S., Blaise, F., Kusiak, C., AstierManifacier, S., and Josette, A. 1993. Heretologous resistance to potato virus $\mathrm{Y}$ in transgenic tobacco plants expressing the coat protein gene of lettuce mosaic potyvirus. Phytopathology 83:818-824.

37. Fan, Z., Dahal, G., Dasgupta, I., Hay, J., and Hull, R. 1996. Variation in the genome of rice tungro bacilliform virus: Molecular characterization of six isolates. J. Gen. Virol. 77:847-854

38. Ghani, M. V., and Khush, G. S. 1988. A new gene for resistance to green leafhopper, Nephotettix virescens (Distant) in rice. J. Genet. 67:151-159.

39. Goff, S. A. 1999. Rice as a model for cereal genomics. Curr. Opinion Plant Biol. 2:86-89.

40. Hasnuddin, A., and Hibino, H. 1989. Grain yield reduction, growth retardation, and virus concentration in rice plants infected with tungro-associated viruses. Pages 56-73 in: Tropical Agriculture Research Series No. 22. Ministry of Agriculture, Forestry and Fisheries, Japan.

41. Hay, J. M., Jones, M. C., Blakebrough, M. L., Dasgupta, I., Davies, J. W., and Hull, R.
1991. An analysis of the sequence of an infectious clone of rice tungro bacilliform virus, a plant pararetrovirus. Nucleic Acids Res. 19:2615-2621.

42. Hayakawa, T., Zhu, Y., Itoh, K., Kimura, Y., Izawa, T., Shimamoto, K., and Toriyama, S. 1992. Genetically engineered rice resistance to rice stripe virus, an insect transmitted virus. Proc. Natl. Acad. Sci. 89:9865-9869.

43. Heinrichs, E. A. 1979. Control of leafhopper and planthopper vectors of rice viruses. Pages 529-560 in: Leafhopper Vectors and Plant Disease Agents. K. Maramarosch and K. F. Harris, eds. Academic Press, New York.

44. Heinrichs, E. A., Rapusas, H. R., Aquino, G B., and Palis, F. 1986. Integration of host plant resistance and insecticides in the control of Nephotettix virescens (Homoptera: $\mathrm{Ci}$ cadellidae) a vector of rice tungro virus. J. Econ. Entomol. 79:437-443.

45. Heong, K. L., Escalada, M. M., and Vo Mai. 1994. An analysis of insecticide use in rice: Case studies in the Philippines and Vietnam. Int. J. Pest Manag. 40:173-178.

46. Hibino, H. 1983. Transmission of two rice tungro-associated viruses and rice waika virus from doubly or singly infected source plants by leafhopper vectors. Plant Dis. 67:774-777.

47. Hibino, H. 1987. Rice tungro virus disease: Current research and future prospects. Pages 2-6 in: Proc. Workshop Rice Tungro Virus 24-27 September 1986. Ministry of Agriculture, Maros, South Sulawesi, Indonesia.

48. Hibino, H. 1989. Insect-borne viruses of rice. Pages 209-241 in: Advances in Disease Vector Research, Vol. 6. K. F. Harris, ed. Springer-Verlag, New York.

49. Hibino, H., and Cabauatan, P. Q. 1987 Infectivity neutralisation of rice tungro-associated viruses acquired by vector leafhoppers. Phytopathology 77:473-476.

50. Hibino, H., and Cabunagan, R. C. 1986. Rice tungro-associated viruses and their relations to host plants and leafhopper vectors. Pages 173-182 in: Int. Sympos. Virus Dis. Rice Leguminous Dis. Trop. Tropical Agricultural Research Series No. 19. Ministry of Agriculture, Forestry and Fisheries, Japan.

51. Hibino, H., Daquioag, R. D., Cabauatan, P. Q., and Dahal, G. 1988. Resistance to rice tungro spherical virus in rice. Plant Dis. 72:843-847.

52. Hibino, H., Daquioag, R. D., Mesina, E. M., and Aguiero, V. M. 1990. Resistances in rice to tungro-associated viruses. Plant Dis. 74:923-926.

53. Hibino, H., Roechan, M., and Sudarisman, S 1978. Association of two types of virus particles with penyakit habang (tungro disease) of rice in Indonesia. Phytopathology 68:1412-1416.

54. Hibino, H., Saleh, N., and Roechan, M. 1979. Transmission of two kinds of rice tungro-associated viruses by insect vectors. Phytopathology 69:1266-1268.

55. Holt, J., and Chancellor, T. C. B. 1996 Simulation modelling of the spread of rice tungro virus disease: The potential for management by roguing. J. Appl. Ecol. 33:927936 .

56. Holt, J., and Chancellor, T. C. B. 1997. A model of plant virus disease epidemics in asynchronously-planted cropping systems. Plant Pathol. 46:490-501.

57. Holt, J., Chancellor, T. C. B., Reynolds, D. R., and Tiongco, E. R. 1996. Risk assessment for rice planthopper and tungro disease outbreaks. Crop Prot. 15:359-368.

58. Huet, H., Mahendra, S., Wang, J., Sivamani, E., Ong, C. A., Chen, L., de Kochko, A., Beachy, R. N., and Fauquet, C. 1999. Near immunity to rice tungro spherical virus 
achieved in rice by a replicase-mediated resistance strategy. Phytopathology 89:10221027.

59. Hull, R. 1996. Molecular biology of rice tungro viruses. Annu. Rev. Phytopathol. 34:275-297.

60. Ilag, L. L., Yadav, R. C., Huang, N., Ronald, P., and Ausubel, F. M. 2000. Isolation and characterization of disease resistance gene homologues from rice cultivar IR64. Gene 255:245-255.

61. Imbe, T., Ikeda, R., Kobayashi, N., Ebron, L. A., Yumol, R. R., Bautista, N. S., and Tambien, R. E. 1995. Genetic studies in relation to breeding rice varieties resistant to tungro disease. In: The Development of Stabilization Technology for Double Cropping in the Tropics. Final report of the IRRI-Government of Japan Collaborative Research Project.

62. Ishii-Eiteman, M. J., and Power, A. G. 1997. Response of green rice leafhoppers to riceplanting practices in northern Thailand. Ecol. Appl. 7:194-208.

63. Isogai, M., Cabauatan, P. Q., Masuta, C., Uyeda, I., and Azzam, O. 2000. Complete nucleotide sequence of the rice tungro spherical virus genome of the highly virulent strain Vt6. Virus Genes 20(1):79-85.

64. Khan, M. A., Hibino, H., Aguiero, V. M., and Daquioag, R. D. 1991. Rice and weed host of rice-tungro associated viruses and leafhopper vectors. Plant Dis. 75:926-930.

65. Koganezawa, H. 1998. Present status of controlling rice tungro virus. Pages 459-469 in: Plant Virus Disease Control. A. Hadidi, R. K. Khetarpal, and H. Koganezawa, eds. American Phytopathological Society, St. Paul, MN.

66. Koganezawa, H., and Cabunagan, R. 1997. Resistance to rice tungro virus disease. Pages 54-59 in: Epidemiology and Management of Rice Tungro Disease. T. C. B. Chancellor and J. M. Thresh, eds. Natural Resources Institute, Chatham, UK.

67. Lenné, J. 2000. Pests and poverty - The continuing need for crop protection research. Outlook Agric. 29:235-250.

68. Ling, K. C. 1966. Nonpersistence of the tungro virus of rice in its leafhopper vector, Nephotettix impicticeps. Phytopathology 56:1252-1256.

69. Ling, K. C. 1969 . Virus diseases of rice in the Philippines and their effect on yield. Sci. Rev. 10:23-30.

70. Ling, K. C. 1974. Capacity of Nephotettix virescens to infect rice seedlings with tungro. Philipp. Phytopathol. 10:42-49.

71. Ling, K. C., and Palomar, M. K. 1966. Studies on rice plants infected with the virus at different ages. Philipp. Agric. 50:165-177.

72. Loevinsohn, M. E. 1984. The Ecology and Control of Rice Pests in Relation to the Intensity and Synchrony of Cultivation. Ph.D. thesis. University of London, London, UK.

73. Manwan, I., Sama, S., and Rizvi, S. A. 1985. Use of varietal rotation in the management of tungro disease in Indonesia. Indones. Agric. Res. Development J. 7:43-48.

74. Manwan, I., Sama, S., and Rizvi, S. A. 1987. Management strategy to control rice tungro in Indonesia. Pages 91-97 in: Proc. Workshop Rice Tungro Virus. 24-27 September 1986. Ministry of Agriculture, Maros, South Sulawesi, Indonesia.

75. Marvier, M. 2001. Can risk analysis "colorize" the black and white of transgenic crops? Online. Plant Health Progress doi: 10.1094/PHP-2001-0831-01-RV.

76. Matteson, P. C. 2000. Insect pest management in tropical Asian irrigated rice. Annu. Rev. Entomol. 45:549-574.

77. Narayanasamy, P. 1972. Influence of age of rice plants at the time of inoculation on the recovery of tungro virus by Nephotettix im picticeps. Phytopathol. Zool. 74:109-114.

78. Nath, P. D., Kenyon, L., Bartolome, V. I., Mclaren, G., and Azzam, O. 2000. Simple serological assays for detecting rice tungro viruses. Food Agric. Immunol. 12:139-151.

79. Nishimura, K., Tanaka, M., Iwaya, K., and Kagabu, S. 1998. Relationship between insecticidal and nerve-excitatory activities of imidacloprid and its alkylated congeners at the imidazoline $\mathrm{NH}$ site. Pestic. Biochem. Physiol. 62:3, 172-178.

80. Normile, D. 2000. Asia gets a taste of genetic food fights. Science 289:1279-1281.

81. Omura, T., Saito, Y., Usugi, T., and Hibino, H. 1983. Purification and serology of rice tungro spherical and rice tungro bacilliform viruses. Ann. Phytopathol. Soc. Jpn. 49:7376.

82. Othman, A. B., Azizah, M. J., and Jatil, A. T. 1999. Surveillance scheme for tungro forecasting in Malaysia. Pages 85-92 in: Proc. Workshop Rice Tungro Dis. Manag. T. C. B. Chancellor, O. Azzam, and K. L. Heong, eds. 9-11 November 1998. Los Baños, Philippines.

83. Ou, S. H. 1985. Rice Diseases. 2nd ed. Commonwealth Agricultural Bureau, Wallingford, UK.

84. Qu, R., Bhattacharya, M., Laco, G. S., De Kochko, A., Subba Rao, B. L., Kaniewska, M. B., Elmer, J. S., Rochester, D. E., Smith, C. E., and Beachy, R. N. 1991. Characterization of the genome of rice tungro bacilliform virus: Comparison with Commelina yellow mottle virus and caulimoviruses. Virology 185:354-364.

85. Ramasamy, C., and Jatileksono, T. 1996. Intercountry comparison of insect and disease losses. Pages 305-316 in: Rice research in Asia: Progress and priorities. R. E. Evenson et al., ed. illus. Ref. CAB International in association with the International Rice Research Institute, Wallingford, Oxon.

86. Rezaul Karim, A. N. M., and Pathak, M. D. 1982. New genes for resistance to green leafhopper, Nephotettix virescens (Distant) in rice, Oryza sativa, L. Crop Prot. 1:483-490.

87. Riley, J. R., Reynolds, D. R., and Farrow, R. A. 1987. The migration of Nilaparvata lugens Stål (Delphacidae) and other Hemiptera associated rice during the dry season in the Philippines: A study using radar, visual observations, aerial netting and ground trapping. Bull. Entomol. Res. 77:145-169.

88. Rivera, C. T., and Ou, S. H. 1965. Leafhopper transmission of 'tungro' disease of rice. Plant Dis. Rep. 49:127-131.

89. Rivera, C. T., and Ou, S. H. 1967. Transmission studies of the two strains of rice tungro virus. Plant Dis. Rep. 51:877-881.

90. Sama, S., Hassanudin, A., Manwan, I., Cabunagan, R. C., and Hibino, H. 1991. Integrated rice tungro disease management in South Sulawesi, Indonesia. Crop Prot. 10:3440.

91. Satapathy, M. K., and Anjaneyulu, A. 1984. Use of cypermethrin, a synthetic pyrethroid, in the control of rice tungro virus disease and its vector. Trop. Pest Manag. 30:170-178.

92. Satapathy, M. K., and Anjaneyulu, A. 1986. Prevention of rice tungro virus disease and control of the vector with granular insecticides. Ann. Appl. Biol. 108:503-510.

93. Satapathy, M. K., and Anjaneyulu, A. 1989. Effect of root zone placement of granular insecticides for tungro prevention and its control. Trop. Pest Manag. 35:51-56.

94. Satapathy, M. K., Chancellor, T. C. B., Teng, P. S., Tiongco, E. R., and Thresh, J. M. 1997. Effect of introduced sources of inoculum on tungro disease spread in different varieties.
Pages 11-21 in: Epidemiology and Management of Rice Tungro Disease. T. C. B. Chancellor and J. M. Thresh, eds. Natural Resources Institute, Chatham, UK.

95. Savary, S., Fabellar, N., Tiongco, E. R., and Teng, P. S. 1993. A characterization of rice tungro epidemics in the Philippines from historical survey data. Plant Dis. 77:376-382.

96. Saxena, R. C., Justo, H. D., Jr., and Palanginan, E. L. 1988. Trap crop for Nephotettix virescens (Homoptera: Cicadellidae) and tungro management in rice. J. Econ. Entomol. 81:1485-1488.

97. Saxena, R. C., Khan, Z. R., and Bajet, N. B. 1985. Neem seed derivatives for preventing rice tungro virus transmission by the green leafhopper, Nephotettix virescens (Distant). Philipp. Phytopathol. 21:88-102.

98. Schoenly, K. G., Cohen, J. E., Heong, K. L., Arida, G. S., Barrion, A. T., and Litsinger, J. A. 1996. Quantifying the impact of insecticides on food web structure of rice-arthropod populations in a Philippine farmers' irrigated field: A case study. Pages 343-351 in: Food Webs: Integration of Patterns and Dynamics. G. A. Polis and K. O. Winemiller, eds. Chapman and Hall, New York.

99. Shen, P., Kaniewska, M., Smith, C., and Beachy, R. N. 1993. Nucleotide sequence and genomic organisation of rice tungro spherical virus. Virology 193:621-630.

100. Shukla, V. D., and Anjaneyulu, A. 1981. Adjustment of planting date to reduce rice tungro disease. Plant Dis. 65:409-411.

101. Shukla, V. D., and Anjaneyulu, A. 1981 Plant spacing to reduce rice tungro incidence. Plant Dis. 65:584-586.

102. Sivamani, E., Huet, H., Shen, P., Ong, C. A., de Kochko, A., Fauquet, C., and Beachy, R. N. 1999. Rice plant (Oryzae sativa L.) containing rice tungro spherical virus (RTSV) coat protein transgenes are resistant to virus infection. Mol. Breed. 5:177-185.

103. Siwi, B. H., and Khush, G. S. 1977. New genes for resistance to the green leafhopper in rice. Crop Sci. 17:17-20.

104. Sogawa, K. 1973. Feeding of the rice plantand leafhoppers. Rev. Plant Prot. Res. 6:3143.

105. Sridhar, R., Ranga Reddy, O., and Anjaneyulu, A. 1976. Physiology of rice tungro virus disease: Changes in chlorophyll, carbohydrates, amino acids and phenol contents. Phytopathol. Z. 94:279-281.

106. Sta. Cruz, F. C., Boulton, M. I., Hull, R., and Azzam, O. 1999. Agroinoculation allows the screening of rice for resistance to rice tungro bacilliform virus. J. Phytopathol. 147(12): 653-659.

107. Sta. Cruz, F. C., Koganezawa, H., and Hibino, H. 1993. Comparative cytology of rice tungro viruses in selected rice cultivars. J. Phytopathol. 138:274-282.

108. Stark, D. M., and Beachy, R. N. 1989 Protection against potyvirus infection in transgenic plants: Evidence for broad spectrum resistance. Bio/Technology 7:1257 1262.

109. Suzuki, Y., Astika, I. G. N., Widrawan, I. K. R., Gede, I. G. N., Astika, N. S., Suwela, N. Aryawan, G. N., and Soeroto. 1997. Epidemiology-oriented forecasting of rice tungro virus disease in asynchronous rice cropping areas. Pages 30-41 in: Epidemiology and Management of Rice Tungro Disease. T. C. B. Chancellor and J. M. Thresh, eds. Natural Resources Institute, Chatham, UK.

110. Suzuki, Y., Astika, I. G. N., Widrawan, I. K. R., Gede, I. G. N., Raga, I. N., and Soeroto. 1992. Rice tungro disease transmitted by the green leafhopper: Its epidemiology and forecasting technology. Jpn. Agric. Res. Q 
26(2):98-104.

111. Swaminathan, M. S. 1984. Rice. Sci. Am. 250(1):62-71

112. Takahashi, Y., Tiongco, E. R., Cabauatan, P. Q., Koganezawa, H., Hibino, H., and Omura, T. 1993. Detection of rice tungro bacilliform virus by polymerase chain reaction for assessing mild infection of plants and viruliferous leafhoppers. Phytopathology 83:655659.

113. Teng, P. S. 1994. Integrated pest management in rice. Exp. Agric. 30:115-137.

114. Thresh, J. M. 1989. Insect-borne viruses of rice and the Green Revolution. Trop. Pest Manag. 35(3):264-272.

115. Tiongco, E. R., Cabunagan, R. C., Flores, Z. M., Hibino, H., and Koganezawa, H. 1993. Serological monitoring of rice tungro disease development in the field: Its implication in disease management. Plant Dis. 77:877-881.

116. Tiongco, E. R., Chancellor, T. C. B., Villareal, S., Magbanua, M., and Teng, P. S. 1998. Roguing as a tactical control for rice tungro virus disease. J. Plant Prot. Trop. 11:45-52.

117. Tiongco, E. R., Flores, Z. M., Koganezawa, H., and Teng, P. S. 1993. Inoculum sources of rice tungro viruses. Philipp. Phytopathol. 29:30-41.

118. Valle, R. R., Nakasuji, F., and Kuno, E. 1986. Development under various photoperiods and thermal unit requirements of four green leafhoppers Nephotettix spp. (Homoptera: Cicadellidae). Appl. Entomol. Zool. 21:571-577.

119. Valle, R. R., Nakasuji, F., and Kuno, E. 1986. A comparative study of the different bionomic and demographic parameters of four green leafhoppers, Nephotettix spp. (Homoptera: Cicadellidae). Appl. Entomol. and Zool. 21:313-321.

120. Villegas, L. C., Druka, A., Bajet, N. B., and Hull, R. 1996. Genetic variation of rice tungro bacilliform virus in the Philippines. Virus Genes 15:1-7.

121. Warburton, H., Palis, F. L., and Villareal, S. 1997. Farmers' perceptions of rice tungro disease in the Philippines. Pages 129-141 in: Pest Management Practices of Rice Farmers in Asia. K. L. Heong and M. M. Escalada, eds. International Rice Research Institute, Manila, Philippines.

122. Way, M. J., and Heong, K. L. 1994. The role of biodiversity in the dynamics and management of insect pests of tropical irrigated rice - A review. Bull. Entomol. Res. 84:567-587.

123. Widiarta, I. N., Suzuki, Y., Sawada, H., and Nakasuji, F. 1990. Population dynamics of the green leafhopper, Nephotettix virescens Distant (Hemiptera: Cicadellidae) in synchronised and staggered transplanting areas of paddy fields in Indonesia. Res. Population Ecol. 32:319-328.

124. Witcombe, J. R., Petre, R., Jones, S., and Joshi, A. 1999. Farmer participatory crop im-

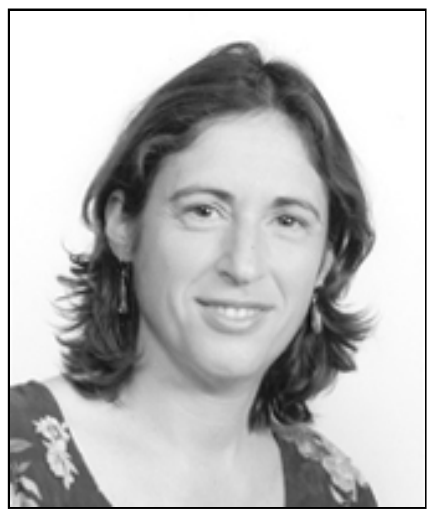

\section{Osmat Azzam}

Dr. Azzam is currently on a leave of absence from the University of Wisconsin (UW)-Madison, where she has managed an NSF project on rice genomics at the Laboratory for Molecular and Computational Genomics since year 2000, and is working with her husband, Dr. Richard Jefferson, on establishing their new company, Monticello Research Australia, in Canberra, Australia. Dr. Azzam has an M.Sc. degree in crop protection from the American University of Beirut in Lebanon and a Ph.D. degree in plant pathology with minors in ecology and biochemistry from Cornell University, Ithaca, NY. After her postdoctoral studies (1991 to 1994) at the Department of Plant Pathology at UW-Madison, Dr. Azzam joined the International Rice Research Institute in the Philippines to lead the virology group there from 1995 to 1999 and to establish a molecular virology facility at the institute. Her research interests include the biology of virus populations, virus resistance, antiviral strategies, and basic virus-host interactions with a special emphasis on rice and beans. During her research, Dr. Azzam has traveled and worked in Central America and South and Southeast Asia.

provement. IV. The spread and impact of a rice variety identified by participatory varietal selection. Exp. Agric. 35(4):471-487.

125. Zhang, S., Lee, G., Davies, J. W., and Hull,

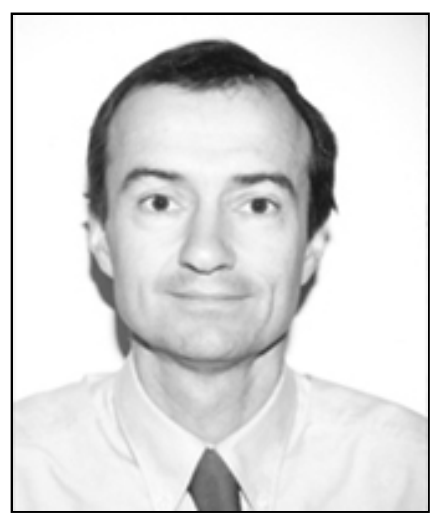

Tim Chancellor

Dr. Chancellor is a principal scientist (entomology) and head of the Plant, Animal and Human Health Group at the Natural Resources Institute, University of Greenwich, UK. He has an M.Sc. in crop protection and a Ph.D. in zoology from the University of Reading. After working as an agriculturist in Indonesia and Ghana, he joined the Natural Resources Institute in 1989. He was seconded to the International Rice Research Institute in the Philippines from 1991 to 1998 . His speciality is the vector ecology and epidemiology of arthropod-borne virus diseases of tropical food crops concentrating on rice, banana, and groundnut. During his research, he has worked in Bangladesh, India, Indonesia, Philippines, and Uganda. 